\title{
Calculation of the foundations in compacted excavations with extended base, applying boundary elements method
}

\author{
Alla Morgun ${ }^{1}$, Ivan Met ${ }^{2}$, Violeta Zadorozhniuk ${ }^{3}$ \\ ${ }^{1,2,3}$ Vinnytsia National Technical University, \\ 21029, Ukraine, Vinnytsya, Khmelnytsky highway 95 \\ 1alla@morgun.com.ua orcid.org/ 0000-0002-4701-339X \\ ${ }^{2}$ vanmet@ukr.net orcid.org/ 0000-0003-0568-730X \\ 33adorozhnyuk.vita@ukr.net orcid.org/0000-0001-9184-5372
}

DOI: $10.32347 / 0475-1132.38 .2019 .28-33$

Summary. Numerical realization according the boundary element method (BEM), intended for the determination of the pressed piles strength with the expanded basis on the base of the provisions of the dispersive soil mechanics is carried out. In the given research the mathematical tool is supplemented with the experimental laws of shearing soil deformation - general regularities of the soil volume change in case of shearing (dilatance and contraction) involving V.M.Nikolaevskyi, I.P.Boiko dilatancy relations are taken into account.

Special attention is paid to practical application of new technology of the predicted calculation of the efficient bored piles carrying capacity -the suggested method of the numerical solution by the boundary element method (BEM) of the springplastic problem of the dispersive soil mechanics, using non-associated plastic flow rule at the nonlinear stage of their work.

BEM is a new numerical approach to the solution of 3D boundary problems, it has considerable advantage - digitization is carried out not in the middle of the studied area where the solution is searched but on its boundary.

Foundations, made of the bored piles are one of the advanced structures, widely used in the construction sphere.

To increase their carrying capacity, the expansion of the pile bases is performed.

The analysis of their efficiency is necessary and the task is actual. Bored piles show high technological and economic efficiency, their wide application is expedient, these piles promote the saving of the materials and economic resources.

In the suggested model the procedure of the step-by-step loading and O.A. Iliushin method of

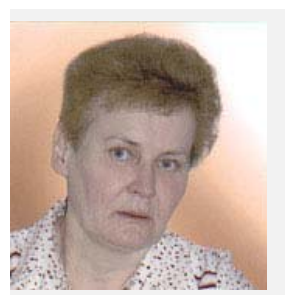

\section{Alla Morgun}

Head of the Department of

Construction, Urban Economy and Architecture

Dr. Sc. (Eng.), Professor

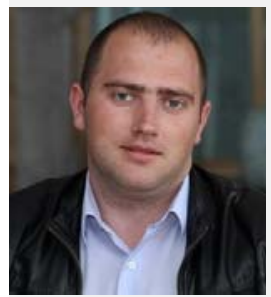

Ivan Met

Associate Professor of the Department of Construction, Urban Economy and Architecture

Ph.D., Assistant Professor

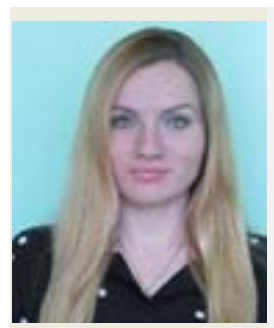

Violeta Zadorozhniuk

Postgraduate student of the

Department of Construction, Urban

Economy and Architecture

Postgraduate student

spring solutions is used ; Mises-Schleichler-Botkin criterian is involved as the criterion of soil work transition into plastic state.

The accumulated technique allows to obtain the stress-strained state of the system "base-bored pile" at all the stages of loading, this state depends both on engineering-geological characteristics of the soil and on the geometry of the foundation. Introduction of modern methods of calculation is one of the ways of reduction the cost of the foundation constructions.

Keywords. Bearing capacity, foundations in compacted excavations, boundary elements method. 


\section{FORMULATION OF THE PROBLEM}

The experience of constructing foundations in compacted excavations shows high technical and economic efficiency of these foundations and the expediency of their wide application in construction practice. Estimate cost of such foundations and labor input are reduced approximately 1.5 times.

Typical advantages of such foundations are increase of carrying capacity and reduction of concrete and metal consumption, volume of earth- moving works.

\section{ANALYSIS OF STUDIES}

Piles, installed in the compacted wells (compacted excavations with expansion) use the advantages of bored and driving piles as the compressed area is created along front face and lateral surface of the pile, that exercises considerable resistance both to vertical and horizontal loadings. Insufficiency of the forecast methods of stress-strain state of such piles restrains the realization of such progressive types of foundations in construction practice.

\section{DEFINITION UNSOLVED ASPECTS OF THE PROBLEM WHICH THE ARTICLE COVERS}

Numerical study according to boundary elements method (BEM) of stress-strain state of the pile $\mathrm{L}=2.6 \mathrm{~m}$ was performed in compacted excavations with different dimensions of the extended bases (with different amount of the compacted crushed stone). Volume of the crushed stone was $0.5 \mathrm{~m}^{3}, 2 \mathrm{~m}^{3}$ and $4 \mathrm{~m}^{3}$. Discretization of active circumpile zone is presented in Fig. 1.2. The idea of construction division(decomposition, discretization) is not a new one, it is known in mechanics and mathematics for a long time, the idea was formulated by Poisson. Nowadays we are at a new stage of application of discretization idea, it is widely used in modern numerical boundary element methods (BEM) and finite element methods (FEM).

\section{THE MAIN MATERIAL}

Change of three-phase soil porosity is connected not only with the sum of main stresses (by compacting pressure) but also with the development of plastic slide deformations. These factors can be taken into account by means of non-linear relations tools between the stresses and deformations, characteristic for plastic flow theory. Total deformations of soil were found in the paper as the sum of an elastic part $\left(\varepsilon_{i j}^{e}\right)$ plastic part $\left(\sum \varepsilon_{i j}^{p}\right)$ and increments of plastic part $\left(d \varepsilon_{i j}^{p}\right)$ :

$$
\varepsilon_{i j}=\varepsilon_{i j}^{e}+\sum \varepsilon_{i j}^{p}+d \varepsilon_{i j}^{p} \delta_{i j}
$$

Increments of plastic part of deformations consisted of the increments of volumetric $d \varepsilon_{i j(\mathrm{vol})}^{p}$, and deviator part $d \varepsilon_{i j(\mathrm{dev})}^{p}$ of deformation tensor:

$$
d \varepsilon_{i j}^{p}=d \varepsilon_{i j(v o l)}^{p}+d \varepsilon_{i j(\mathrm{dev})}^{p}
$$

For adequate description of non-linear processes of soil spring-plastic model, based on plastic flow theory in the form of nonassociated plastic flow law (3) and dilatancy relations of V.M. Nikolaevsky and I.P. Boiko (4) $[1,4]$ was used.

$$
\begin{aligned}
& d \varepsilon_{i j}^{p}=d \lambda \frac{d F}{d \sigma_{i j}}, \quad F \neq f ; \\
& d \varepsilon_{i j(v o l)}^{p}=\Lambda(\chi) d \gamma^{p},
\end{aligned}
$$

wher $F$ - is plastic potential - thermodynamic function of state, determines «dilatancy» of the environment - change of its volume in case of the slide; $f$ - is the criterion of the transition to boundary state; $d \lambda$ - is a scalar coefficient of porous load; $d \gamma^{p}-$ is increment of slide intensity; $\Lambda(\chi)$ - is dilatancy rate [3].

Transition of the soil into plastic state was determined by Mises-Schleikher-Botkin criterion: 


$$
\mid \begin{aligned}
& f=T+\sigma_{m} \cdot \operatorname{tg} \psi-\tau_{S} \text { if } \sigma_{m} \leq p_{0} \\
& f=T+p_{0} \cdot \operatorname{tg} \psi-\tau_{S} \text { if } \sigma_{m}>p_{0}
\end{aligned}
$$

where $f$ - is yield criterion; $\sigma_{m}$ - is hydrostatical pressure; $T$ - is the intensity of deviator stress; $\psi-$ is the angle of internal friction on octahedral plane; $\tau_{S}$ - is a parameter, analogous to bonding; $p_{0}-$ is a parameter of soil ground that characterizes the transition from the cone to the cylinder in Mises-SchleikherBotkin criterion.

The solution of the system of differential equations of pile balance in the soil, which K. Brebbia and I. Talleth [2] reduced to the equivalent integral equation (6), is performed by BEM, applying O.Illushin method of elastic solution in the form with additional loads.

$$
c_{i j} u_{j}+\int_{\Gamma} \rho_{i j}^{*} u_{i j} d \Gamma=\int_{\Gamma} u_{i j}^{*} \rho_{i} d \Gamma+\int_{\Omega} \dot{\sigma}^{*} \dot{\varepsilon}_{j k}^{p} d \Omega,
$$

where $u-$ is the set vector of displacement speeds on the boundary of the pile; $p-$ is the required vector of stresses on the surface of the pile; $u^{*}, p^{*}, \dot{\sigma}^{*}$ - are boundary equation kernals, R. Mindlin fundamental solutions for displacements, stresses, and derivatives from stresses under the action $P=1$ in the middle of elastic semiplane; integral over domain $\Omega$ in (6) includes the vector of plastic deformation of the foundation $\varepsilon_{p}$.

After submission of the calculation scheme of the pile in the form of finite-element system (Fig. 1, 2, 3) the task was reduced to the solution of the system of linear algebraic equations (SLAE) $A \cdot Y=F$ at each step of loading where
$A-$ is an influence matrix of BEM, $Y-$ is the required vector of stresses on the boundary surface of the pile, $F$ - is the vector of the prescribed displacements.

Three types of experimental foundations with the extended base and different amount of crushed stone, length of pile prior to extension was $L=2.6 m$ were considered (Fig. 1,2).

Volume of the crushed stone was $0,5 \mathrm{~m}^{3}$, $4 \mathrm{~m}^{3}$. In the experiment [5] the crushed stone was tamped by portions of $0,5 \mathrm{~m}^{3}$ then the concrete was put in the body of the foundation. According to [5] soil compaction to $\gamma=1.6 \frac{t}{m^{3}}$ was performed on $0,4-0,6 \mathrm{~m}$ downwards and off the expansions. Correspondingly, in numerical study the dimensions of the active area of base were taken (Fig. 1,2).

Experimental ground to the depth of 7-8m consists of clayed sand that are referred to the first type of additivity. As the input parameters weighted-average site survey soil characteristics are taken: $E=15970 \mathrm{kPa}, \quad v=0.3$, $\rho=1.7 \mathrm{t} / \mathrm{m}^{3}, \quad \rho^{\min }=1.57 \mathrm{t} / \mathrm{m}^{3}, \quad \rho^{\max }=2.19 \mathrm{t} / \mathrm{m}^{3}$, $\varphi=0.387 \mathrm{rad}, c=8 \mathrm{kPa}$.

The results of numerical studies applying BEM technique were compared with the data of in-place -tests [5], that simultaneously is test problem for verification of the convergence of the accepted mathematical model of soil deformation.

The results of the comparison of numerical and in-place-studies are presented in Table 1.

Табл. 1. Результати порівняння чисельних та натурних досліджень

Table 1. Results of the comparison of numerical and in-place studies

\begin{tabular}{|c|c|c|}
\hline $\begin{array}{c}\text { Volume of the compacted crushed } \\
\text { stone }\end{array}$ & $\begin{array}{c}\text { Carrying capacity }(\mathrm{kN}) \text { by } \\
\text { BEM if } S=3 \mathrm{~cm}\end{array}$ & $\begin{array}{c}\text { Data of in-plase study of car- } \\
\text { rying capacity according to [5] } \\
\text { if } S=3 \mathrm{~cm}\end{array}$ \\
\hline $0,5 \mathrm{~m}^{3}$ & $593 \mathrm{kN}$ & $600 \mathrm{kN}$ \\
\hline $2 \mathrm{~m}^{3}$ & $987 \mathrm{kN}$ & $1000 \mathrm{kN}$ \\
\hline $4 \mathrm{~m}^{3}$ & $1600 \mathrm{kN}$ & $1580 \mathrm{kN}$ \\
\hline
\end{tabular}


Loads P ( $(\mathrm{kN})$

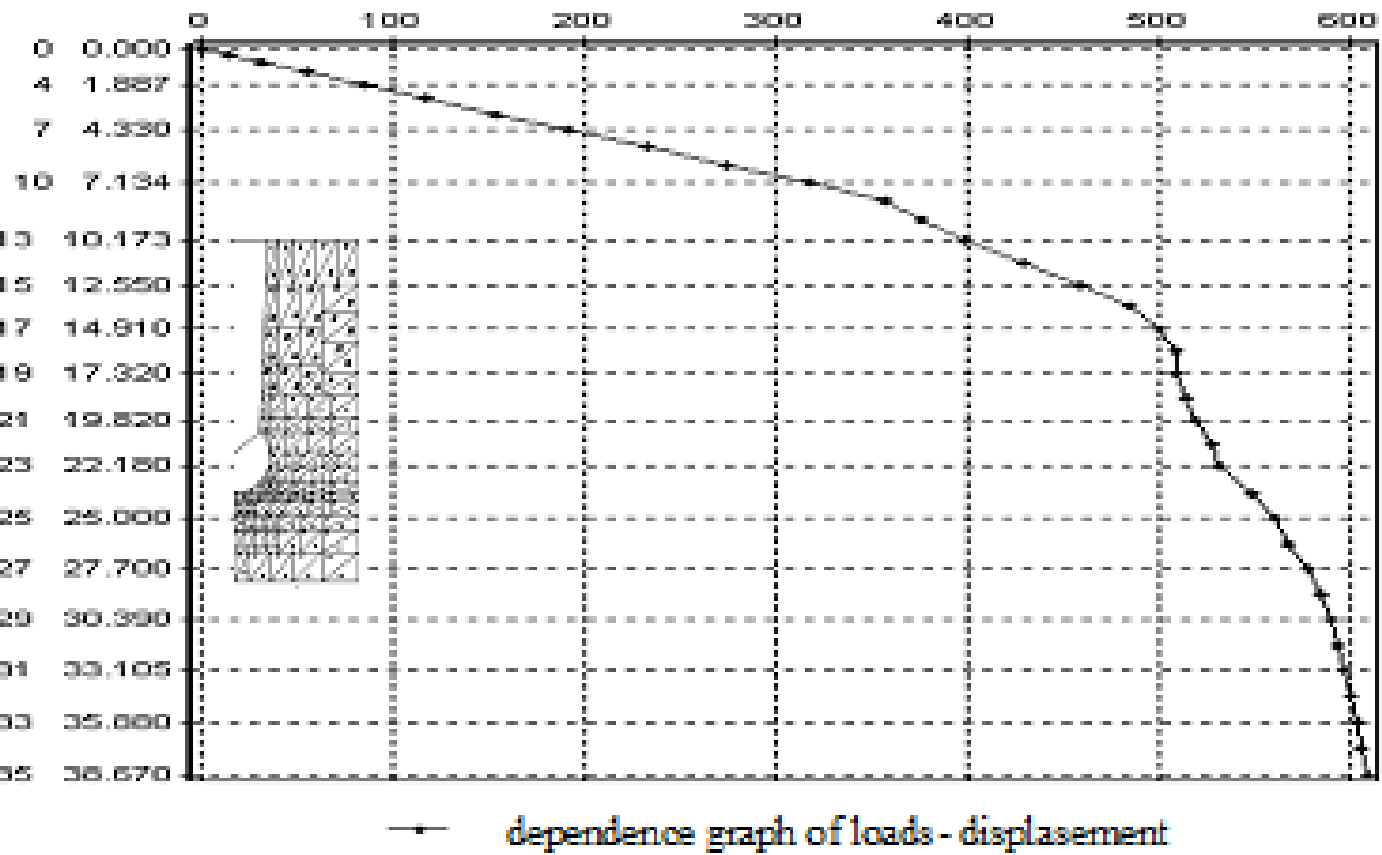

Рис.1. Графік «Р-s» у випадку ущільнення гравію $0,5 \mathrm{~m}^{3}$.

Fig.1. Graph «P-s» in case of $0,5 \mathrm{~m}^{3}$ of gravel compaction.

\section{Loads $\mathrm{P}(\mathrm{kN})$}

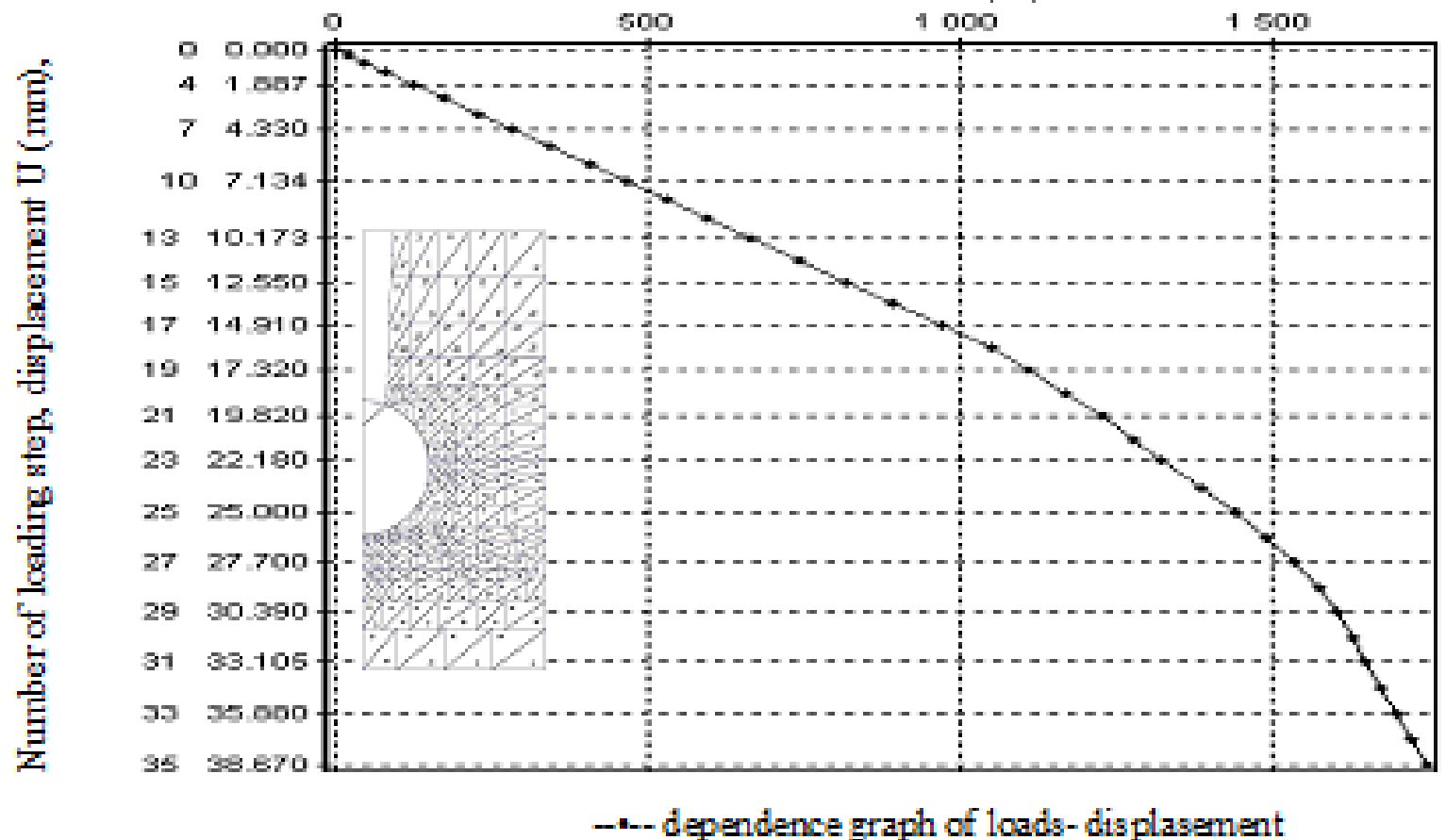

Рис.2. Графік «Р-s» у випадку ущільнення гравію $4 \mathrm{~m}^{3}$.

Fig.2. Graph «P-s» in case of $4 \mathrm{~m}^{3}$ of gravel compaction. 


\section{CONCLUSIONS}

Numerical studies, carried out, prove high degree of their correspondence to experimental data. Introduction of new modern methods of calculation - is one of the ways, aimed at cheapening of the cost of foundation constructions.

Stress-strain calculations allow to obtain the values of carrying capacity and setting of piles maximally close to-real-life conditions. Considerable increase of piles resistance in the compacted excavations is stipulated by the formation around the compacted excavation the area of the compacted soil that promotes the increase of the area of load transfer from the pile on the soil of normal density.

Thus, the piles in compacted excavations are characterized by rather high technical economic induces and they deserve wide propagation.

\section{ЛІТЕРАТУРА}

1. Бойко І.П. Напружено-деформований стан грунтового масиву при побудові нових фундаментів поблизу існуючих будинків / І.П. Бойко, О.В. Сахаров // Основи $i$ фундаменти: Міжвідомчий науково технічний збірник. - К.: КНУБА.- 2004. Вип. 28.- С. 3-10.

2. Бреббия К. Методы граничных елементов / К. Бреббия. Ж. Теллес, Л. Врубел.: пер. с англ. Л. Г. Корнийчука. - М: Мир, 1987. $524 \mathrm{c}$.

3. Моргун А.С. Нелінійні проблеми механіки грунтів: монографія. А.С. Моргун Вінниця, ВНТУ. - 2016. - 122 с.

4. Николаевский В. Н. Современные проблемы механики грунтов / В. Н. Николаевский // Определяющие законы механики грунтов. М.: Стройиздат.1975.- С. 210-227.

5. Крутов В.И. Конструкции фундаментов в вытрамбованных котлованах для объектов агропромышленных комплексом в сейсмических районах. / В.И. Крутов, В.В. Стародворский, В.М., Шаевич К.М: Стройиздат. ОФМГ № 5, 1983. - 8-11 с.

\section{REFERENCES}

1. Boiko I.P., Sakharov O.V. (2004). Napruzhenodeformovanyi stan gruntovoho masyvu pry pobudovi novykh fundamentiv poblyzu isnuiuchykh budynkiv [Stress-strain state of soil body in the process of new foundations construction near the existing buildings]. Osnovu $i$ fundamenty: Mizhvidomchyj naukovotekhnichnyj zbirnyk. Kyiv: KNUBA, 28, 3-10 (in Ukrainian).

2. Brebbia K., Telles G., Vrubel L. (1987). Metodyi granichnyih elementov [Boundary elements technique]. per. s angl. L. G. Korniychuka. Moskva: Mir. 524 (in Russian).

3. Morgun A.S. (2016) Neliniini problemy mekhaniky hruntiv: monohrafiia. [Nonlinear problems of soil mechanics: monograph]. Vinnytsia, VNTU, 122 (in Ukrainian).

4. Nikolaevskiy V.N. (1975) Sovremennyie problemyi mehaniki gruntov [Modern problems of soil mechanics]. Opredelyayuschie zakonyi mehaniki gruntov. Moskva: Strojizdat, 210 - 227. (in Russian).

5. Krutov V.I.,

Starodvorskiy V.V., Shaevych V.M. (1983) Konstruktsii fundamentov $\mathrm{v}$ vyitrambovannyih kotlovanah dlya ob'ektov agropromyishlennyih kompleksom $\mathrm{v}$ seysmicheskih rayonah [Constructions of the foundations in compacted excavations for the objects of agrarian - industrial complexes in seismic regions]. OFMG, 5. Moskva: Strojizdat, 8-11 (in Russian).

\section{Розрахунок фундаментів у витрамбуваних котлованах $з$ розширеною основою за методом граничних елементів}

\author{
Алла Моргун, \\ Іван Меть, \\ Віолета Задорожнюк
}

Анотація. Проведено числову реалізацію за МГЕ визначення несучої спроможності штампованих паль 3 розширеною основою на основі положень нелінійної механіки дисперсних грунтів. В роботі математичний апарат доповнено експериментальними законами зсувного деформування грунту враховано загальні закономірності зміни об'єму грунту при зсуві (дилатансію та контракцію) 3 залученням дилатансійних співвідношень В.М. Ніколаєського, І.П. Бойка. 
Особливе місце приділено практичному прикладанню нової технології прогнозного розрахунку несучої спроможності ефективних буро набивних паль - запропонованого методу числового розв'язку за методом граничних елементів (МГЕ) пружно-пластичної задачі механіки дисперсних грунтів 3 використанням в нелінійній стадії їх роботи неасоційованого закону пластичної течії. МГЕ - новий числовий підхід до розв'язку тривимірних крайових задач, має суттєву перевагу - дискретизація в ньому здійснюється не в середині дослідної області, в якій шукається рішення а на іiі границі.

Фундаменти із буро набивних паль $є$ однією iз прогресивних конструкцій, яку широко використовують у будівництві. Для збільшення ix несучої спроможності влаштовують розширення в п'ятах паль. Необхідний конкретний аналіз їх ефективності, задача $\epsilon$ актуальною. Буро набивні палі показують високу техніко-економічну ефективність, доцільність їх широкого використання, сприяють економії матеріалів і енергетичних ресурсів.

В запропонованій моделі використано процедуру крокового навантаження та метод пружних рішень О.А. Ільюшина. В якості критерію переходу роботи грунту в пластичний стан залучено критерій Мізеса-ШлейхераБоткіна. Напрацьована методика дозволяє на всіх етапах навантаження отримувати напружено-деформований стан системи «основа-буронабивна паля», який залежить як від інженерно-геологічних характеристик грунту, так i від геометрії фундаменту. Впровадження сучасних нових методів розрахунку - один із шляхів здешевлення кошторисних фундаментних конструкцій.

Key words. Несуча спроможність, фундаменти у витрамбуваних котлованах, метод граничних елементів. 